\title{
Student Youth Legal Consciousness: Formation Problems and Prospects
}

\section{Conciencia jurídica de los jóvenes estudiantes: problemas y perspectivas de formación}

\author{
Elena V. Mischenko \\ Doctor of Law, Professor, Dean of Law Faculty, Orenburg State University, Orenburg, Russia \\ ORCID ID: 0000-0003-4065-2209
}

Tatyana N. Kriskovets

Doctor of Education, Associate Professor of the Department of Pedagogics of High School, Orenburg State Pedagogical University, Orenburg, Russia. ORCID ID: 0000-0003-3554-4107

Anastasia P. Lopanova

$\mathrm{PhD}$ in Education, Senior Teacher of the Department of the Organization of Judicial and Public Prosecutor's and Investigative Activity, Orenburg State University, Orenburg, Russia. ORCID ID: 0000-0002-5443-7369

Isita V. Muskhanova

Doctor of Education, Professor, Head of the Institute of Philology, History and Law, Chechen State Pedagogical University, Grozny, Russia.

ORCID ID: 0000-0001-8302-4312

Kazban S. Inalkaeva

PhD in Law, Associate Professor, Head of the Department of Law Disciplines, Chechen State Pedagogical University, Grozny, Russia.

ORCID ID: 0000-0001-6234-4480

Tatiana I. Shulga

Doctor of Psychology, Professor of the Department of Social Psychology, Moscow Region State University (MGOU), Moscow, Russia.

ORCID ID: 0000-0002-3584-6087

\section{Alla V. Ivanova}

$\mathrm{PhD}$ in Education, Associate Professor, Head of the Department of Musical Instruments and Solo Singing, Chuvash State Pedagogical University named after I.Y. Yakovlev, Cheboksary, Russia. ORCID ID: 0000-0001-9115-108X

Received 09-08-20 Revised 10-10-20

\section{* Correspondence}

Email: map_1234@mail.ru

\section{Accepted 12-12-20 On line 03-12-21}

\section{Citation:}

Elena V. Mischenko, Tatyana N. Kriskovets, Anastasia P. Lopanova, Isita V Muskhanova, Kazban S. Inalkaeva, Tatiana I. Shulga, Alla V. Ivanova. (2021). Student Youth Legal Consciousness: Formation Problems and Prospects. Propósitos y Representaciones, 9 (SPE3), e1135. Doi http://dx.doi.org/10.20511/pyr2021.v9nSPE3.1135 


\begin{abstract}
The Article Relevance. In order to build the state of law and civic society, it is necessary to increase legal education of all citizens of the state in the field of human rights and freedoms, forms and methods of their protection. It is especially important to involve young people in this process actively, instill in them the desire to know more about their rights and show more interest in the legal field. The aim of the study is a systematic analysis of the legal consciousness of young people and the forms of organization of legal education of young people. Research methods: as a research method, a questionnaire survey was used as a method of collecting primary information, which allows determining the level of development of the legal consciousness of students. Research results: the article analyzes the forms of organization of young people's legal education; recommendations on the use of forms of organization of young people's legal education are developed. The novelty and originality of the study lies in the fact that for the first time the legal activity of students was studied. The low awareness of students about the laws on the rights of youth and the youth environment was revealed. It is shown that the core in the formation of a young person's social activity is ideological nature. It is revealed that students allocate informing, training, consulting and propagandizing forms of legal education of young people. It is shown that in higher educational institutions, legal education of young people is organized through training, informing and propagandizing forms through seminars, lectures, round tables, discussion clubs, mass media, printed publications, the Internet, social advertising. It is determined that for the organization of youth legal education one should take into account the wishes of the students: to develop programs of volunteerism, including the legal education of young people as activity; to develop a network of free youth agencies, in which young people can get all kinds of advice; regularly hold free legal aid. Insufficient legal literacy of students and unwillingness of the majority of students to participate in the solution of any social problems are revealed. It is shown that students demonstrate political passivity due to frustration and distraction of moral guidelines. Practical significance: The data obtained in this work can be used in legal psychology, jurisprudence, pedagogy, as well as for further theoretical development of this issue.
\end{abstract}

Keywords: student youth, legal consciousness, legal education.

\title{
Resumen
}

La relevancia del artículo. Para construir el estado de derecho y la sociedad cívica, es necesario incrementar la educación jurídica de todos los ciudadanos del estado en el campo de los derechos humanos y las libertades, formas y métodos de su protección. Es especialmente importante involucrar a los jóvenes en este proceso de forma activa, inculcarles el deseo de conocer más sobre sus derechos y mostrar más interés en el ámbito jurídico. El objetivo del estudio es un análisis sistemático de la conciencia jurídica de los jóvenes y las formas de organización de la educación jurídica de los jóvenes. Métodos de investigación: como método de investigación se utilizó una encuesta por cuestionario como método de recolección de información primaria, que permite determinar el nivel de desarrollo de la conciencia jurídica de los estudiantes. Resultados de la investigación: el artículo analiza las formas de organización de la educación jurídica de los jóvenes; se elaboran recomendaciones sobre el uso de formas de organización de la educación jurídica de los jóvenes. La novedad y originalidad del estudio radica en que por primera vez se estudió la actividad jurídica de los estudiantes. Se puso de manifiesto el escaso conocimiento de los estudiantes sobre las leyes sobre los derechos de la juventud y el entorno juvenil. Se demuestra que el núcleo en la formación de la actividad social de un joven es de naturaleza ideológica. Se revela que los estudiantes destinan formas de informar, capacitar, asesorar y difundir la educación jurídica de los jóvenes. Se demuestra que en las instituciones de educación superior la educación jurídica de los jóvenes se organiza a través de formas de formación, divulgación y propaganda a través de seminarios, conferencias, mesas redondas, clubes de discusión, medios de comunicación, publicaciones impresas, Internet, publicidad social. Se determina que para la organización de la educación jurídica juvenil se deben tener en cuenta los deseos de los estudiantes: desarrollar programas de voluntariado, incluyendo la educación jurídica de los jóvenes como actividad; desarrollar una red de agencias juveniles gratuitas, en las que los jóvenes puedan recibir todo tipo de consejos; obtener asistencia 
jurídica gratuita con regularidad. Se revelan la falta de conocimientos legales de los estudiantes y la falta de voluntad de la mayoría de los estudiantes para participar en la solución de cualquier problema social. Se demuestra que los estudiantes demuestran pasividad política debido a la frustración y distracción de las pautas morales. Importancia práctica: Los datos obtenidos en este trabajo pueden ser utilizados en psicología jurídica, jurisprudencia, pedagogía, así como para un mayor desarrollo teórico de este tema.

Palabras clave: juventud estudiantil, conciencia jurídica, educación jurídica.

\section{Introduction}

Legal education of the population, especially students of the Russian Federation, is very relevant today, which has been repeatedly noted by the country's top leadership (Klimenko \& Rumynina, 2002; Cheshegorov, 2002; Grishnova, 2005). It is young people who will play an important role in the development of civic society and the state of law (Vasenina, 2007; Ilyinsky, 2000; Razumovskaya et al., 2018; Sorokoumova \& Cherdymova, 2020; Cherdymova, 2015). To the problems of legal education, it should be added that, as a rule, there are opinions in society that already developed and adopted laws do not work or do not work at all levels. At present, a targeted policy of the state, specialized organizations, the law corporation and the work of each participant in the process is necessary, aimed at improving the legal culture of the younger generation in order to further successful socialization of the individual (Agranovskaya, 1988; Gaponenko, 1991; Vengerov, 2000). Socialization can be considered as a process carried out in an organized manner, with a goal set and with the help of certain techniques (Galiskan et al., 2019). It is in this way that the opposition of an individual's activity to the influence of the environment can be noted (Gulina, 2002; Kudryavtsev, 1982; Tapchanyan, 1998). In our opinion, the degree of manifestation of civic consciousness and patriotism among young people is largely determined by the degree to which young people feel their involvement in this state.

It is possible to note the general political passivity of students in solving any social and environmental problems of society. Young people do not see the opportunity to take part in solving these problems and feel involved in civic society, and thus their own legal growth is hindered. A civic society can be considered an association of free citizens of their country, based on the right and guarantee of a person's free choice of forms of economic and political activity, where equality of all citizens before the law is ensured (Volkova, 1999; Kalandarishvili, 2004).

Therefore, a number of laws that have different directions both in the field of social and legal support for young people, and in the formation of a holistic scientific worldview, including culture and patriotism, provides the social policy of the state in modern Russia.

Youth is a driving force in the development and formation of civic society in Russia. Nevertheless, to do this, it must have a strong sense of civic responsibility for its actions or inaction, it must have an active civic position, it must be united by common ideas, and this is often not the case. This happens because it comes into life in the context of an economic crisis and a difficult situation of social development of society (Aseev, 1976; Kharchev \& Alekseeva, 1977; Petrov, 2000). Many students are not sure that they will be in demand, that they will find their place in life; they cannot look into the future and even more so predict it. The time has come for young people to engage in youth policy actively, which, of course, will also affect the development of civic society, but for this, an important condition is to increase the level of legal literacy and legal culture of young people (Sinyukova, 2002; Lukashcheva, 1986; Nikitin, 2002; Uledov, 1980; Rudenko et al., 2018; Bayanova et al., 2019; Leshchenko, 2016).

In recent years, various changes can be noted in Russia that have affected the existence of most public organizations of student youth. As the directions of state policy, we can name such as educational activities of citizens; educational activities in terms of legal education of the younger generation; introduction of new legal courses in the educational process; organization of free legal assistance. One of the priorities of the state youth policy now is the development of educational work 
with young people, innovative training and educational technologies, as well as the creation of conditions for self-education of young people (Sokolov, 1974; Sinyukova, 1998; Tatarintseva, 1990; Naumenkova, 2009; Ryabtsev, 2005; Mironova et al., 2017). Social and legal education in any modern society is an important part of state policy. The process of building a state of law begins with a broad awareness of everyone's rights and obligations.

Thus, one of the most important areas of state policy is to ensure the availability of legal information, the development of a system of legal education and information of citizens, including the development of information and legal resources and ensuring the effective functioning of information and reference systems. Legal education is a complex and multidimensional system of activities, in which the educational system plays a special role.

\section{The Study Objectives and Structure}

75 students took part in the questionnaire survey. The objectives of the study were to characterize the forms of organization of young people legal education; to develop recommendations on the use of forms on organization of young people legal education.

For students, it is possible to introduce legal education in stages, while for non-students, it is necessary to use all forms of legal education, but in practice, this type of activity is quite complex in stages.

During the pilot study, it was revealed that the organization of legal education of youth is conducted in educational institutions, universities, the Internet by means of: informing (lectures, publications, Internet), training (social studies lessons, lectures, educational and methodical manuals), consulting (advice of a lawyer, social worker, Internet) and promoting (media, social advertising, print media) forms. Stage by stage technologies of legal education are typical for students.

The following questions were used in the questionnaire:

Do you know the laws concerning the rights of young people?

Do you know the law on the provision of free legal assistance in the Russian Federation?

What do you know about this law?

Do you consider it necessary?

What legal advice is most needed by the population?

From whom did you learn about this law?

Have your rights ever been violated?

Do you think it is worth educating young people about their rights?

What forms of legal education, in your opinion, are the most effective? (you can specify several of them)

The reporting in the questionnaire was welcomed: sufficiently complete, striving to be as succinct as possible, which contained the main results and their analysis, with formulation of conclusions and suggestions.

\section{Results}

\section{Manifestation of the Features of Student Legal Consciousness}

One of the tasks of the study was to identify the forms of legal education that are in demand among students. However, the term legal education caused some wariness among students. The following answers were received to the question: What forms of legal education, in your opinion, are the most effective? - students' answers were divided equally between the options of lectures (25\%), seminars $(31 \%)$ and distribution of printed materials $(15 \%), 35 \%$ of respondents consider the creation of special Internet sites to be the most effective form of legal education. Only $21 \%$ of students know about the laws related to free legal aid in the Russian Federation, 25\% have heard and 54\% have never heard about the entry into force of the law. Of the $21 \%$ of respondents who answered positively in the second question, $3 \%$ learned about the law from friends, $13 \%$ from the media and $13 \%$ from 
teachers and work colleagues. To the question about the Federal Law, the paragraphs of which are related to free legal assistance to the population, namely: What legal advice is most necessary for the population? The following answers were received, which are most necessary: a legal framework related to legal awareness and legal education of the population (35\%); presentation of basic guarantees for the implementation of citizens right to legal assistance, which is free and sufficiently qualified (45\%); knowledge about consumer protection (75\%). In the opinion of students, the following types of such assistance should be provided: slightly less than half of the respondents (43\%) spoke about oral and written counseling; the majority of respondents noted the need for assistance in drawing up an application, complaint, petition and other documents of a legal nature $(89 \%)$; slightly more than half of the respondents $(55 \%)$ noted the need for assistance in court proceedings and in state and municipal bodies, organizations.

According to students, only specialists with higher legal education (100\%) can provide free legal assistance. To the question: Have your rights ever been violated? - The vast majority of $89 \%$ answered positively, respectively, $11 \%$ gave a negative answer. To the question: In your opinion, is it worth educating young people? - $96 \%$ of respondents gave a positive answer, $4 \%$ - said that it was not necessary.

Summing up the analysis of the questionnaire data obtained, we can state an extremely low awareness of the laws on the rights of young people and the youth environment, and frequent violations of rights by young people. At the same time, it is impossible to say about the absolute passivity of young people, since almost all respondents note the need for legal education. The survey showed that the organization of legal education of youth is conducted in universities, the Internet by informing (lectures, publications, Internet), training (social studies lessons, lectures, educational and methodical manuals), consulting (advice of a lawyer, social worker, Internet) and propagandizing forms (media, social advertising, print media). As a recommendation for the organization of youth legal education one should note the following student responses: to develop a program of volunteerism, including the legal education of young people as activity area; to develop a network of free youth agencies, in which young people can get all kinds of advice; regularly hold free legal aid; to use for all entities of youth policy the social advertising as a resource of legal education; to organize online forums to discuss youth policy.

The modern world has limited opportunities for educational activities. The availability of reliable information becomes one of the most necessary riches for a person. Who owns the information, owns the world. At the same time, the huge flow of legal information is often not reliable, not correct, complicates the orientation in it. In this regard, the systematization of legal information flow is extremely difficult, since in the modern world it is not controllable, it is extremely significant. That is why modern youth policy should be primarily aimed at forming the worldview of young people.

\section{Discussions}

A peculiar form of harmonious human development is the legal culture, which can simultaneously be the provision and observance of the law rule. Law-making activity forms the foundation and basis of each state.

At present, taking into account the current events, in many regions of the Russian Federation, there is such a problem among young people that in the conditions of crisis, young people cannot find a use in life, they are disappointed and deprived of moral guidelines, and they are not sufficiently literate in the field of legislation and youth policy (Takhumova et al., 2019). Currently, legal culture can be considered as a reproducing value, the only global form and as a kind of national legal phenomena. The state, legal systems and legal order are distinguished as legal phenomena. To implement the social policy of the state, it is necessary to take into account the entire system of measures that are aimed at respecting the rights of every citizen, respecting the ability of every citizen to participate in various social, economic, environmental, and spiritual spheres of life freely. Thus, all elements of the structure of society should be protected by social policy from the negative impact of any processes. The effectiveness of the state's social policy is determined by the degree of 
social groups' satisfaction, in particular young people, with their position in society, the level and quality of life of the young generation.

At the same time, the youth policy of the Russian Federation is imperfect, and effective mechanisms for involving young people in the development of civil society, in political activity, and in priority innovative projects are currently being established.

The basic principles of the law is to ensure social and legal protection of young people, necessary to compensate age-related deficiencies of their social status; provision of a young citizen social services for spiritual and physical development, learning, education, training, volume, species and quality of which provide for the full development of personality and preparation for independent living; fostering a proactive community activities in the field of social, spiritual and physical development of young people. Legal culture and legal consciousness, including legal literacy (knowledge of legal norms and norms of the law), attitude to the laws and internal orientation to compliance with the laws and legal activity of the individual, can be a reflection of the legal level of students.

The legislative framework of the Russian Federation, without any doubt, is aimed at orienting of all aspects of young people life, all their social activities. These are housing programs, health programs, and support programs for young families. At the same time, the problems of political and social passivity of young people with their growing aggressiveness are increasingly raised in the mass media and printed publications.

Democratic political directions among the youth often completely destroy the chain of command and implanted permissiveness. In parallel with political illiteracy among young people, young people often do not have information about their rights, and forget about their responsibilities.

The forms of organizing legal education for young people used in the Soviet period are currently not properly adapted, although in many regions of Russia, social services are actively searching for innovative forms of legal education. Studies have shown that among young people, forms of legal education are certainly in demand, but today young people are extremely poorly aware of the legal framework, their rights and obligations, and are poorly oriented in terms of concepts. Legal education of young people is an activity that represents a system of educational and training activities aimed at the formation of a legal culture.

\section{Conclusions}

Today's youth is in a difficult situation, as young people are currently one of the most vulnerable social groups in society. Young people should be an active entity of the reformation process. It is its active position that determines the quality of today's social transformations, the consistency and continuity of the reforms carried out in society, and, as a result, the future development of society. Therefore, this situation of young people in society causes the need for a successful social policy aimed at solving the problems of young people.

The main task currently facing the state in relation to such a social group as young people is to educate patriotic young people with independent thinking, having a creative worldview, professional knowledge, and being able to make decisions independently aimed at improving the well-being of the country, the people and their families. for students.

Printed leaflets, Internet sites have little PR, which is why they do not give the proper result

A number of laws that have different directions both in the field of social and legal support for young people, and in the formation of a holistic scientific worldview, including culture and patriotism, provides the social policy of the state in modern Russia. Legal education of young people is an activity that represents a system of educational and training activities aimed at the formation 
of social and legal culture. The organization of legal education of young people is carried out through informing, consulting and propagandizing forms. One should consider the following recommendations of students on the organization of socio-legal education of young people: to develop programs of volunteerism, including the legal education of young people as activity area; to develop a network of free youth agencies, in which young people can get all kinds of advice; regularly hold free legal aid; to use for all entities of youth policy the social advertising as a resource of legal education; to organize online forums to discuss youth policy.

Thus, when studying the legal activity of students, it was revealed that the core in the formation of a young person's activity is ideological nature. In the system of legal policy, students are divided into several areas: social policy in the field of education, health, employment and social and labor relations, as well as pension, cultural, family and youth social policy. Students allocate informative, educational, consulting and propagandizing forms of legal education of young people. In higher educational institutions, legal education of young people is organized through educational, informative and propagandistic forms through seminars, lectures, round tables, discussion clubs, mass media, printed publications, the Internet, and social advertising. Among young people, there is such a problem that in a crisis, young people cannot find a use in life; they can feel disappointed because of the lack of a moral vector and due to the lack of a sufficient level of literacy in the field of youth policy. As a result, young people are becoming more passive, not seeking to take part in solving various environmental, social, economic and other issues, and demonstrating legal passivity. Young people do not see opportunities to participate in solving various issues that arise in society. Young people do not seek to develop a sense of responsibility and duty to their society, there is some stagnation of their personal growth, and as a result, society itself suffers due to the lack of active members.

\section{References}

Agranovskaya, Yu.A. (1988). Legal culture and ensuring the rights of the individual. Moscow: Nauka.

Aseev, V.G. (1976). Motivation of behavior and formation of personality. Moscow: "Mysl".

Bayanova, A.R., Sizova, Z.M., Chistyakov, A.A., Prokopyev, A.I., \& Vasbieva, D.G. (2019). A philosophical view of organizational culture policy in contemporary universities. European Journal of Science and Theology, 15(3), 121-131.

Caliskan, S., Guney, Z., Sakhieva, R.G., Vasbieva, D.G., \& Zaitseva, N.A. (2019). Teachers' Views on the Availability of Web 2.0 Tools in Education. International Journal of Emerging Technologies in learning, 14(22), 70-81.

Cherdymova, E.I. (2015). The problem of existence of future specialist eco-professional consciousness. Azimuth of scientific research: pedagogy and psychology, 3(12), 56-58.

Cheshegorov, V.V. (2002). Righteousness and morality in the pedagogical interaction. Specialist, 2 , 27-32.

Gaponenko, N.V. (1991). Legal culture in the Soviet state administration: essence and formation. Krasnoyarsk: Nauka.

Grishnova, E.E. (2005). Legal culture in the political space of modern Russia. Moscow: Nauka.

Gulina, O.R. (2002). Historical roots and peculiarities of legal nihilism in modern Russia: PhD Thesis. Ufa.

Ilyinsky, I.M. (2000). Youth of the planet: the global situation in the 90s, trends and prospects. Moscow: Publishing House of the Institute of Youth.

Kalandarishvili, Z.N. (2004). Deformation of the legal consciousness of young people and legal ways to overcome it: theoretical and legal aspect: $\mathrm{PhD}$ Thesis. St. Petersburg.

Kharchev, A.G. \& Alekseeva, V.G. (1977). Way of life, morality, education. Moscow: Law and right.

Klimenko, A.V. \& Rumynina, V.V. (2002). Theory of State and Law. Moscow: Mastership.

Kudryavtsev, V.N. (1982). Legal behavior: norm and pathology. Moscow: Nauka.

Leshchenko, O.V. (2016). The role of structural components of legal consciousness in the formation of legal and value attitudes of minors. Law: History, Theory, practice: materials of the IV International Scientific Conference. St. Petersburg: Molodoy Ucheny, pp. 8-11 
Lukashcheva, E.A. (1986). Law, morality, personality. Moscow: Nauka.

Mironova, M.D., Zaitseva, N.A., Larionova, A.A., Akhpolova, V.B., Glagoleva, L.E., Belozerova, J.M. (2017). Features of Innovative Personnel Management of Service Companies in the Period of Implementation of Organizational Changes. Eurasian journal of analytical chemistry. 12(5B), 793-802.

Naumenkova, K.V. (2009). Genesis of legal consciousness in Russia. Spiritual and historical readings: materials of the regional scientific and practical conference. Krasnoyarsk: Institute of Advanced Training of Siberian Federal University, pp. 58-65.

Nikitin, A.F. (2002). Fundamentals of social science: textbook for IX grade of secondary schools. Moscow: Drofa.

Petrov, V.R. (2000). Deformation of the legal consciousness of Russian citizens. (Problems of theory and practice): $\mathrm{PhD}$ Thesis. N. Novgorod.

Razumovskaya, M.I., Larionova, A.A., Zaitseva, N.A., Orekhov, V.D., Trufanova, S.N., Korzhanova, A.A., \& Takhumova, O. (2018). Modeling the network integration space for educational programs. Modern Journal of Language Teaching Methods, 8(5), 56-67.

Rudenko, L.G., Larionova, A.A., Zaitseva, N.A., Kostryukova, O.N., Bykasova, E.V., Garifullina, R.Z., Safin, F.M. (2018). Conceptual model of training personnel for small business services in the digital economy. Modern journal of language teaching methods, 8(5), 283-296.

Ryabtsev, R.A. (2005). Legal education as a method of forming legal consciousness in the context of modern legal reform. Political and legal problems of citizens' education. Collection of scientific works. Krasnodar. Moscow: Moscow State Pedagogical University.

Sinyukova, T.V. (1998). Legal consciousness and legal education. Theory of state and law under the editorship of N.V. Matuzova. Moscow: Yurist.

Sinyukova, T.V. (2002). Legal consciousness and legal education. Theory of State and Law. Moscow: Yurist.

Sokolov, N.Ya. (1974). Organization of legal propaganda. Moscow: Yurist.

Sorokoumova, E.A. \& Cherdymova, E.I. (2020). Study of the relationship between civil identity and environmental attitudes of students. The category of "social" in modern pedagogy and psychology. Materials of the 8th All-Russian scientific and practical conference with remote and international participation. Scientific and Educational center "Perspektiva". Ulyanovsk, 493-496.

Takhumova, O.V., Larionova, A.A., Zaitseva, N.A., Povorina, E.V., Vikhrova, N.O., Bykasova, E.V., \& Zhukov, V.A. (2019). Usage of regions' innovative activity assessment results for the National Cluster Policy development. Dilemas Contemporaneos-Educacion Politica y Valores, 6(SI), 54, Article number 54.

Tapchanyan, N.M. (1998). Legal consciousness and legal culture of the individual in the conditions of Russia renewal: PhD Thesis. Krasnodar.

Tatarintseva, E.V. (1990). Legal education (methodology and methodic): methodical manual. Moscow: Vyshaya shkola.

Uledov, A.K. (1980). Spiritual life of society. Moscow: Yurist.

Vasenina, I.V. (2007). Value orientations of student youth. Higher education in Russia, 11, 116 119.

Vengerov, A.B. (2000). Theory of State and Law: textbook for law high schools. Moscow: Jurisprudence.

Volkova, A.N. (1999). Pedagogical aspect of political culture formation: PhD Thesis. Rostov-onDon. 